\title{
An Intercultural Analysis of Personal Metadiscourse in English and Chinese Commencement Speeches
}

\author{
Yuting Zhu* \\ School of Foreign Languages, Central China Normal University, No. 152, Luoyu Road, Hongshan District, Wuhan City, Hubei \\ Province, 430079, PR China
}

Corresponding Author: Yuting Zhu, E-mail: yuting_zhu123@qq.com

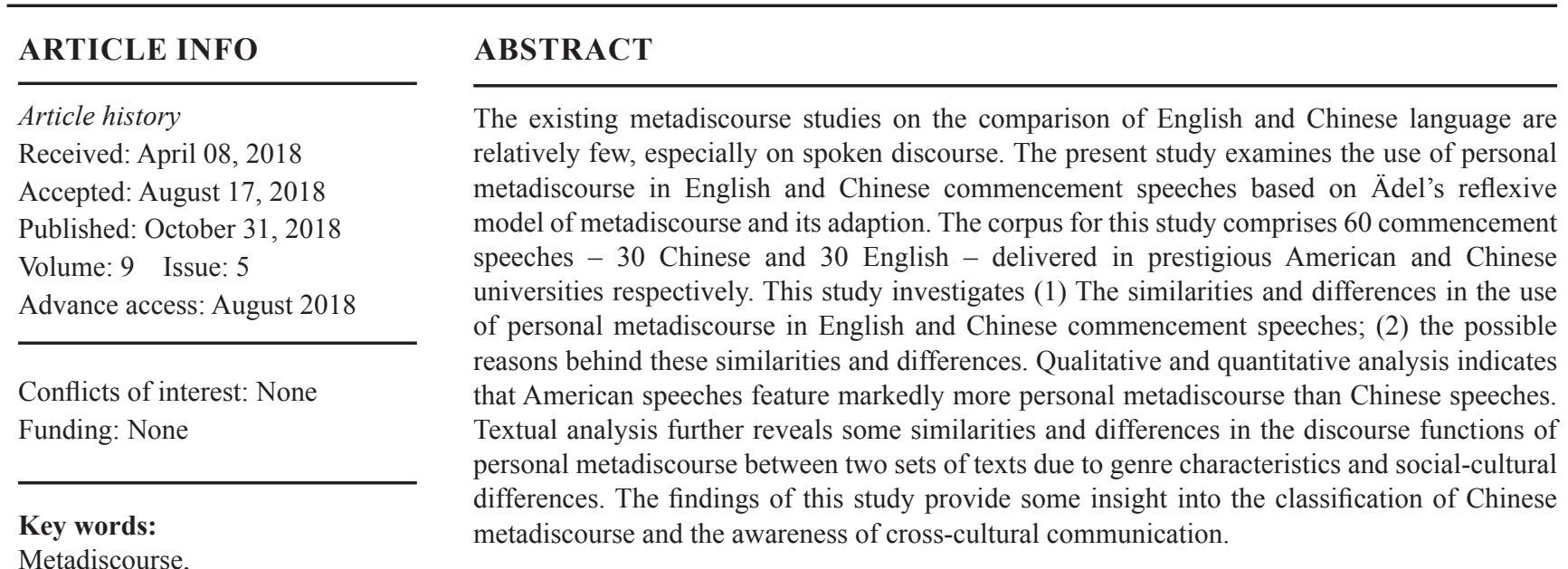

Metadiscourse,

Commencement Speeches,

Personal Metadiscourse,

English Language,

Chinese Language,

Comparative Study,

Discourse Function

\section{INTRODUCTION}

Metadiscourse has become the interest of academic research since its first appearance in applied linguistics, driven by the function of metadiscourse as a rhetorical resource in relating language to its contexts of use (Hyland, 2017). Due to its conceptually rich and analytically powerful nature, metadiscourse studies have come across difficulties and fuzziness in its definition, classification and analysis. Generally, there are two definitions formed in the study of metadiscourse: one which takes a broad definition and approach, seeing textual interaction as fundamental to the category, and one which uses a narrow definition and approach, seeing discourse reflexivity as fundamental to the category (Ädel \& Mauranen, 2010). This study takes the reflexive model and employs Ädel's (2010) classification of metadiscourse to examine the use of personal metadiscourse in English and Chinese university commencement speeches. Therefore, in this study, metadiscourse in defined as "discourse about the evolving discourse, or the writer's explicit commentary on her own ongoing text" (Ädel, 2006).

As mentioned above, metadiscourse reflects the relationship between language and its contexts of use. In other words, metadiscourse is context-specific, which means we should put the study of metadiscourse in specific context or discourse. So far, many scholars have investigated metadiscourse in different registers. For example, Zhang (2016) undertook a comprehensive linguistic analysis of metadiscourse markers in written registers. By using the Freiburg update of the Lancaster-Oslo/Bergen Corpus of British English as database, the researcher examined register variation of metadiscourse markers across the press, general prose, academic prose and fiction. Following this study, Zhang et al. (2017) conducted a similar research to examine register variation of metadiscourse markers in spoken language. Some scholars examine the use of metadiscourse in specific genre such as textbooks (Crismore, 1984; Hyland, 1999), academic research articles (Abdi, 2002; Dahl, 2004; Hu \& Cao, 2011; Hyland, 1998; Jiang \& Hyland, 2017; Kim \& Lim, 2013; Salas, 2015), college students' essay (Ädel, 2006; Cheng \& Steffensen, 1996; Crismore, Markkannen, \& Steffensen, 1993; Ho \& Li, 2018; Intaraprawat \& Steffensen, 1995; Lee \& Deakin, 2016; Yoon, 2017), post-graduate dissertation (Bunton, 1999) and casual conversation (Schiffrin, 
1980). Among the existing studies on metadiscourse, researches in written discourse have been widely investigated, especially in academic writing, while few studies have been conducted to examine the use of metadiscourse in spoken registers (Ädel, 2010, 2012; Amelia, Michela, \& Giuseppe, 2006; Bu, 2014; Buttny \& Hashim, 2015; Gordon \& Luke, 2016; Guillem, 2009; Kelly, Cunningham, \& Ricketts, 2017; Lee \& Subtirelu, 2015; Mai, 2016; Mauranen, 2003, 2010; Tang, 2017; Thompson, 2003; Zare \& Tavakoli, 2017).

It's noticed that few studies on metadiscourse have been conducted in spoken registers, let alone the comparative study between English and Chinese languages. Therefore, the present study undertakes a comparative study to investigate the use of personal metadiscourse in spoken discourse, focusing on English and Chinese university commencement speeches. As a specific genre, university commencement speech gains society's attention due to its important role in student's education and social life. To speak effectively, commencement addressers need to take the audience into consideration. The addressers should make the organization of information in the speech clearly presented to the audience and make their own values and advices accepted by the audience. One way that writers can effectively reach their audiences is through the features in a text that have been labeled metadiscourse (Intaraprawat \& Steffensen, 1995). Therefore, metadiscourse is an important persuasive power in commencement speech.

In response to the issues identified above, this study aims to investigate cultural, language and genre-related influences on the use of personal metadiscourse by comparing English and Chinese commencement speeches delivered in American and Chinese universities. More specifically, it seeks to answer the following two questions:

(1) What are the similarities and differences in the frequency and diversity of the use of personal metadiscourse and its discourse functions in English and Chinese commencement speeches?

(2) What are the factors causing these similarities and differences?

\section{LITERATURE REVIEW}

The term metadiscourse was first put forward by Zelling Harris in 1959 to offer a way of understanding language in use, representing a writer's or speaker's attempts to guide a receiver's perception of a text.

Since its appearance in academic works, metadiscourse has become a fuzzy item in terms of its definition, classification and pragmatic functions. Some analysts study both the textual and interpersonal functions of metadiscourse (Ädel, 2006; Cheng \& Steffensen, 1996; Crismore et al., 1993; Hyland, 1998, 2004), while other analysts have narrowed the focus of metadiscourse to features of textual organization (Mauranen, 1993; Valero-Garcés, 1996) or explicit illocutionary predicates (Beauvais, 1989). Therefore, it is an important and necessary part to clearly define this term, and set up a classification system for our own research.

\section{The Classification of Metadiscourse Proposed by Ädel}

In this study, we employ Ädel's (2006) notion of metadiscourse, seeing metadiscourse primarily as a form of linguistic reflexivity. Metadiscourse serves metalinguistic, expressive and directive functions of language, based on Roman Jakobson's model of six basic linguistic functions. According to Ädel, metadiscourse is thus defined as "discourse about the evolving discourse, or the writer's explicit commentary on her own ongoing text" (Ädel, 2006). This means that the main components of metadiscourse include the discourse, or text itself (the metalinguistic function) and also potentially the writer/speaker persona (the expressive function) and the real or imagined audience (the directive function). One important point in Ädel's model is that the referential function is excluded, as it refers to entities in the 'real world', outside of the world of discourse.

We focus on Ädel's (2010) taxonomy of metadiscourse. Drawing on the reflexive model, Ädel (2006) makes a distinction between personal and impersonal metadiscourse. Ädel (2006, p. 47) defines personal metadiscourse as instances of metadiscourse that make "direct reference to the writer and/or reader of the current text, either by means of pronouns (primarily I, we, you and their oblique and possessive forms) or nouns (such as writer, author, and reader)." Expressions such as "as I showed above" (Ädel, 2006, p. 48), and "as you will see" (Ädel, 2006, p. 162) are examples of personal metadiscourse. As Ädel (2006, p. 20) points out, what is in focus in personal metadiscourse is "how writers and readers relate to the world of discourse (or the text), or how they relate to each other within that world." Impersonal metadiscourse, however, refers to those instances of metadiscourse that "does not make explicit reference to the discourse participants" (Ädel, 2006, p. 14). Instead of using pronominal and nominal references to the writer or the reader, passive voice and other impersonal constructions maybe used to avoid explicit self or other presentation in impersonal metadiscourse. Expressions such as "as shown above" and "to conclude" are instances of impersonal metadiscourse (Ädel, 2006, p. 48).

The above-mentioned personal and impersonal metadiscourse provides a superficial division of metadiscourse and a searching method for potential metadiscourse in computer-assisted discourse analysis. However, a more detailed and deeper classification system is needed. Thus, Ädel's (2010) classification of metadiscourse based on different discourse functions is employed in present study. Within the taxonomy, a primary distinction is made between "Metatext", which is primarily oriented toward the code/discourse itself, and "Audience interaction", which is primarily oriented toward the audience. Metatext is then divided into three different groups: metalinguistic comments, discourse organisation, and speech act labels; Audience interaction comprises one category, called references to the audience. More specifically, metalinguistic comments consist of discourse functions of repairing, reformulating, commenting on linguistic form/ meaning, clarifying, and managing terminology. Repairing refers to speaker or writer's self or other-initiated correctness of previous statement. Reformulating, different from 
repairing, provides alternative terms or expressions for the purpose of expansion. Commenting on linguistic form or meaning engages making metalinguistic references to the use of certain words and expressions. Clarifying is used when addresser is trying to specify the intention and avoid any misunderstanding. The last subcategory managing terminology is used when a new term or definition is given.

Discourse organization comprises discourse functions dealing with topic management: introducing topic (used to open the topic), delimiting topic (used to specify the constraints of the topic), adding to topic (used when adding a certain topic or subtopic), concluding topic (used to close a topic) and marking asides (used to open or close a 'topic sidetrack' or digression). Discourse organization also comprises functions dealing with phorics management, which are used when pointing to different locations and portions in the current discourse. These category consists of enumerating, endophoric marking, previewing, reviewing, and contextualizing. Enumerating is used to order different parts of the discourse. Endophoric marking is used to draw the attention of the audience to specific location of the discourse. For example, when the audience is instructed to look at a table, or turn to a specific point in a handout. Previewing and reviewing involve pointing forward and backward respectively in the discourse to inform what has been stated and what is about to be stated. Finally, contextualizing is used to comment on (the conditions of) the situation of writing or speaking, thus containing the traces of the production of the discourse.

The speech act labels category consists of arguing which is used to stress the action of arguing for or against an issue, exemplifying which is used to give explicit examples, and a general category of other speech act labelling for those speech acts which are not frequently used (e.g., remind, share, quote, offer, point out and list). With regard to the last category reference to the audience, there are some specific discourse functions included such as managing comprehension/channel, managing audience discipline, anticipating the audience's response, managing the message, and imaging scenarios. Managing comprehension or channel occurs when the addresser wants to check the participants' understanding of the ongoing discourse. Managing audience discipline refers to directly addressing the participants and in some cases complimenting or reprimanding them for their behavior. Anticipating the audience's response is used when the addresser predicts probable reactions of the participants to what is said. Managing the message requires emphasizing the main part of the discussion for the audience to remember. Imagining scenarios occurs when the audience are asked to suppose something in the shared world of discourse.

\section{The Modification of Ädel's Classification}

Based on Ädel's classification, we slightly modify it and add another three new subcategories or new discourse functions into the original one (see figure 1). There are some reasons for adding new categories. Firstly, it's widely acknowledged that metadiscourse is an open category. When we analyze different texts of different registers, it's natural to come across more new types of metadiscourse. Secondly, Ädel also mentioned that "the taxonomy is likely to need further revision, but it can be seen as a first attempt at creating a comprehensive taxonomy" (Ädel, 2010). Ädel put forward the classification system based on material from academic lectures, but in our research, the data is university commencement speech which is different from Adel's. Thirdly, in the process of data analysis, other metadiscursive expressions are found with functions independent enough to stand as a separate subcategory, so we add another three new discourse functions to the original one.

The three new subcategories are connecting topic, saying and calling for the audience attention to the following content. Connecting topic is added to the discourse organization part to manage topics. It is used to link topics and create salient coherence relations in discourse. For example, in (1) (2), you know and you see here don't have a very concrete meaning but just function as a discourse marker connecting two topics, which makes the discourse more coherent.

(1) ...took on the job, now it's your turn, welcome. You

know I once had a friend, who had a rich uncle...

(2) It was not what I had expected. You see, when it came to my career, in 1998, I was also adrift.

This subcategory usually contains the expressions you know and you see. As discourse markers, the discourse functions of you know and you see have been studied by many scholars (House, 2009; Li, 2009; Qiao, 2008; Ran, 2002; Rintaniemi, 2017; Xu, 2008). In most cases, the two discourse markers are regarded as linguistic elements that have little or no semantic meaning but procedural meaning. As House (2009) argues that the main function of you know is highly speaker-oriented: its purpose is to create salient coherence relations and help the speaker when he or she is having difficulties in planning the utterance. In addition, $\mathrm{Xu}$ (2008) points out that you know has some discourse functions as repairing marker, addition marker, insufficiency marker and turn government marker. As for the discourse marker you see, Zhong (2013) argues that it contains pragmatic functions as change marker, addition marker and repair marker. Through these studies, we can draw a conclusion that as discourse markers, the discourse functions of you see and you know are very similar to each other. Whatever pragmatic functions these two discourse markers possess such as repairing, adding and shifting topics, I summarize these functions to one major function and call it connecting topic and classify this discourse function to main category discourse organization. In Chinese language, the corresponding expression with this discourse function is in most cases the expression "ni zhi dao (you know)".

The second new subcategory in my study is saying which involves general verba dicendi such as say, speak, talk or write (Ädel, 2006, p. 63). I classify this discourse function into the category speech act labels. The new subcategory is borrowed from Ädel to indicate the action of saying whose main function is "to remind the reader of the main topic while bringing up some fact that is important to the argumentation." The following are some examples in English commencement speeches of this study: 


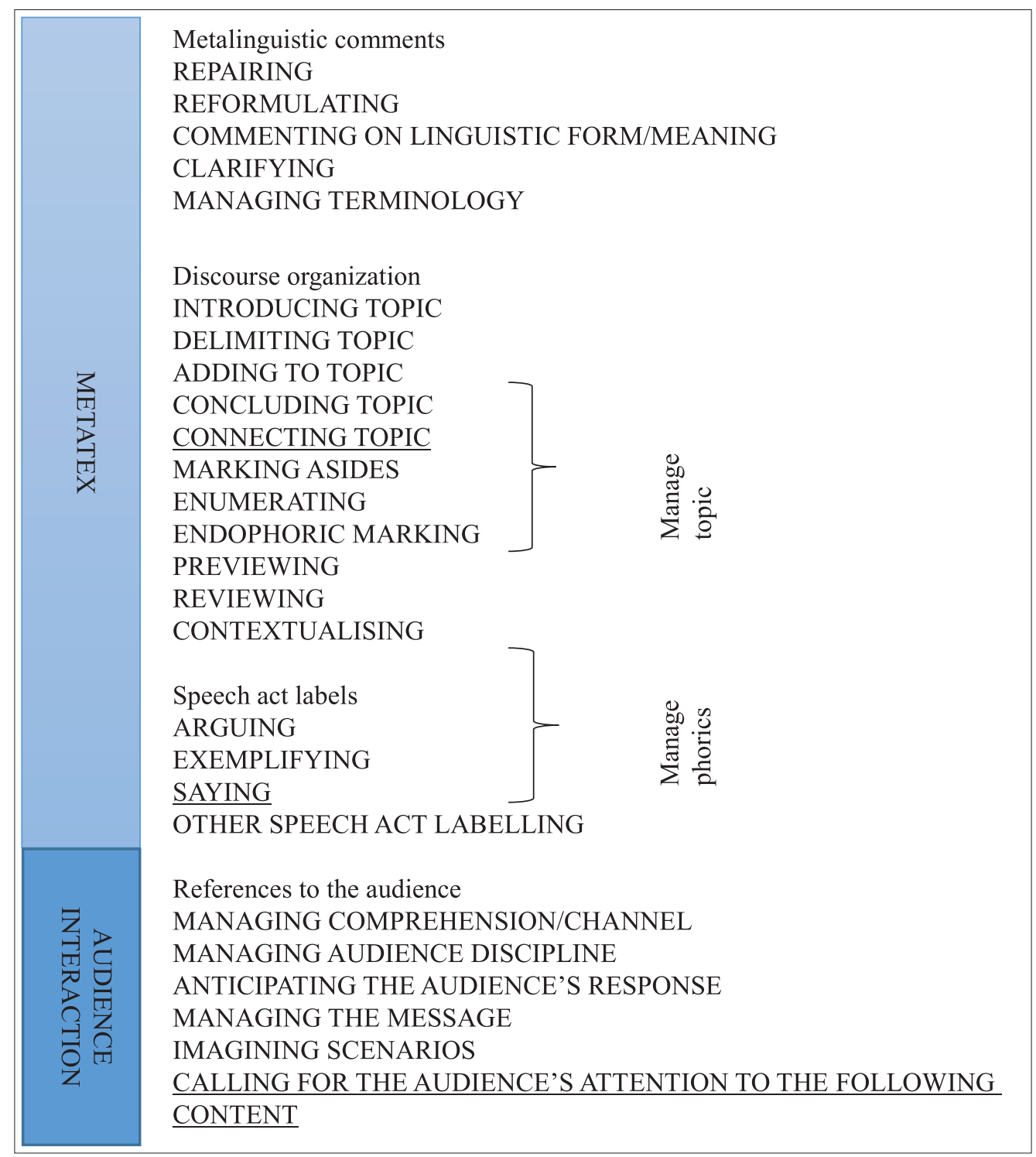

Figure 1. The modified taxonomy of metadiscourse based on Ädel (2010)

(3) first part of the test. But with the rest let me say upfront, and I mean this sincerely, there's...

(4) all those geniuses who never get this chance? I'm talking about the young people from right here.

(5) our community continue to make bad choices. And I have to say, growing up, I made quite a few myself...

(6) hours that we can never get back? To this I say: you can always trust that when you're coming...

In most cases, this discourse function saying includes some verbs like say, speak and talk about. In Chinese corpus, this subcategory contains some expressions like "wo xiang shuo", "wo yao shuo" which mean "I want to say...". Here are some examples of this kind in Chinese corpus:

(7) 在复旦学习的东西很多都是看似无 用的, 但我要说, 很可能复旦给你 们的这些貌似无用的东西...

In Fudan University, many things you've learned seem to be useless. But I have to say, it's likely that these seemingly useless things...

(8) 要留下人生足迹, 就必须一步一个 脚印。我更想说, 今天的中国社会 , 给你们的 路太多...
If you want to leave your footprints in your life journey, you must take one step at a time. I want to say that in today's society, you have too many choices...

(9) 同学们, 在今天的毕业典礼上, 我 要说, 你们今天收获的不仅仅是文 凭，更是自 信...

My dear students, at the graduation ceremony today, I have to say what you gain today is not just diploma, but also self-confidence...

The last new subcategory added to Ädel's model is calling for the audience attention to the following content. And it belongs to the category reference to the audience. When analyzing two corpus of commencement speech, I came across many metadiscursive expressions like "I will tell you...", "let me tell you...", "I speak to you...". It is a kind of interaction with the audience, but I couldn't find an appropriate place to put them in Ädel's classification for the functions of "wo gao su ni (I tell you)" are mostly informing, reaffirming, directing, warning and reminding. Dong argues that the main function of this expression is emphasizing or calling for the audience's attention to the ongoing text. Although Dong has put forward five discourse functions, I take our 
research focus of metadiscourse into consideration and label metadiscouse containing this kind of expression as calling for the audience attention to the following content. There are some examples in both corpus:

(10). like to plant a kiss on a life lived fully. And I can tell you from experience that, once you under...

(11) as you want it to be. My job today is to tell you don't believe it. Because as tough as things...

(12) of choices every day. But I'm here to tell you, you can find the balance between ambition and ..

(13) 你们即将离开学校奔赴世界各地。 临行前我要骄傲地告诉大家, 这几 年你们用实际行动 ...

You are leaving school and going to all parts of the world. Before leaving, I would like to tell you proudly that in recent years you have taken practical action...

(14) 进入大学只是真正学习的开始。今 天, 我也想告诉你们, 本科毕业只 是 事业成 功的 开始...

Entering university is the beginning of real learning. Today, I also want to tell you that graduation is just the beginning of a successful career...

(15) 学位, 是知识学习层次的标度。我 想告诉你们的是, 这种量度和标度 是 一 时 的 ...

Degree is the measurement of knowledge learning. What I want to tell you is that such measurement is temporary...

\section{RESEARCH METHODOLOGY}

Two corpuses were built-English corpus and Chinese corpus, each of them containing 30 commencement speeches respectively. The speeches were collected from the website https://www.baidu.com/. All 60 speeches were delivered in Chinese and American famous universities (eg., Harvard university, Stanford university, Fudan university) from the year of 2010 to 2017. All the materials are the transcription of oral commencement speeches of the two languages. The total number of words in English corpus is 91 838. And the total number of words in Chinese corpus is 75194.

AntConc 3.2.4 was used to process material. According to Ädel (2006), personal metadiscoure includes pronouns (primarily I, we, you and their oblique and possessive forms) or nouns (such as writer, author, and reader). Considering the linguistic features in spoken discourse, the following items were searched in English corpus: I, we, you, me, my, your, us, our, ourselves, everyone. As for the Chinese corpus, since the transcription of Chinese speeches have been segmented which means if we put in "我(I)" as keyword, we can get al. lists of “我(I)”, “我们(we)”, “我的(my)”, “我们的(our)”. So we only need to search few items as “我(I)", “你(you)”, “ 大家(everyone)”, “各位(everybody)”, “同学们 (students)”. After searching these words, we need to manually identify whether it is a metadisursive expression or not, and also to identify the discourse functions of each personal metadiscoure.

As for identifying the metadiscursive expressions, according to Ädel (2010, p. 75), the three criteria for metadiscourse are as follows: "explicitness", "world of discourse", "current discourse", and-for personal types of metadiscourse "speaker-writer qua speaker-writer" and "audience qua audience". The "explicitness" criterion refers to the explicit commentary on the ongoing discourse. The "world of discourse" criterion indicates that the action should take place in the world of discourse rather than in the "real world". The "current text" criterion states the fact that metadiscourse makes reference to the current text rather than other texts. The same principle is applied to the current addresser and the current addressee, with the requirement that they be talked about or referred to in their roles as discourse participants or in other words, in the world of discourse.

In this study, we only focus on personal metadiscourse that means only expressions containing personal pronouns that direct the audience's attention to discourse and influence their interpretation of the discourse qualify as metadiscourse. The following examples are given for better understanding the notion of metadiscourse, in which the metadiscursive expressions are illustrated in italics.

(16) reviewing: isn't dirty, you haven't been in the game. I spoke earlier about definitions of personal success...

(17) enumerating: And that actually brings me to the second lesson I want to share about leading a rich life and...

(18) introducing topic: 在这个讲台上, 我的心 情也很不平静, 愿意与大家分享一 点自己的时间印记。我和我的同龄 人...

introducing topic: On this stage, I am not in a quiet mood, and I'd like to share with you some of my stories. My peers and I...

(19) concluding topic: 而且也是我们应该坚持 的地方。所以我想总结我们复旦培 养的学子, 不仅仅不是匠人...

concluding topic: and that's what we should stick to. Therefore, I'd like to draw a conclusion that our Fudan students are not just craftsman...

There still exists one job to do after identifying all the metadiscourse. It is noticed that when we search for the items "I" and "you" respectively, the metadiscourse markers "I" and "you" co-occur in one sentence and are counted twice. According to Ädel, metadiscourse markers signal metadiscourse, and metadiscourse is realized by metadiscourse markers and their surrounding linguistic expressions which may also be metadiscourse markers (Ädel, 2006, pp. 48-52). However, in this research, our focus is metadiscourse not metadiscourse markers. Therefore, after collecting all metadiscourse expressions, we have to check them and delete the same metadiscourse.

\section{RESULTS AND DISCUSSION}

As shown in table 1, the total number of metadiscourse found in English commencement speeches were 211, and the Chinese speeches 62, which were the raw frequency of personal metadiscourse. In order to get more accurate results, we counted the normalized frequency of personal metadiscourse in two corpuses. The results showed that on average there were 23 personal metadiscourse per 10000 words in English speeches and 8 in Chinese speeches. Apparently, personal 
metadiscourse used in English speeches was far more frequent than that of Chinese speeches.

Personal metadiscourse focuses on "how writers and readers relate to the world of discourse (or the text), or how they relate to each other within that world." Commencement speech as a kind of spoken communication involves interaction between addressers and addressees. In this respect, the use of personal metadiscourse is an effective means for speakers to establish harmonious relationship with the audience and achieve their goals of delivering the speech.

However, as a whole, personal metadiscourse was more frequently used in English commencement speeches than in Chinese. The reason is that apparently there were far more personal pronouns in English than in Chinese (see Table 1). Chinese is a parataxis language which means it uses less linguistic forms to achieve coherence. In addition, Chinese language is more loose in structure and has many no-subject sentence. What's more, under the influence of Confucianism, Chinese people are more implicit and indirect in showing their views and thinking, while to some extent, English addresser are opposite. English is a hypotaxis language which needs overt linguistic forms to connect phrases or sentences and to present logic meanings. Therefore, in Chinese speeches, the number of personal pronouns mainly serving as the subject of an utterance is significantly less than in English speeches.

As for the distribution of personal metadiscourse with different functions, we can see from table 2 that in both speeches, the category metatext was more frequently used than audience interaction. This is due to genre-related factor.

Table 1. Description of the data

\begin{tabular}{lcc}
\hline & $\begin{array}{c}\text { English } \\
\text { corpus }\end{array}$ & $\begin{array}{c}\text { Chinese } \\
\text { corpus }\end{array}$ \\
\hline $\begin{array}{l}\text { Total number of words } \\
\text { Average number of words per text } \\
\text { Total number of pronouns (personal }\end{array}$ & 3061838 & 75194 \\
$\begin{array}{l}\text { I, we, you, and their oblique and } \\
\text { possessive forms) and nouns (such as } \\
\text { the graduates, everyone, etc.) }\end{array}$ & 7897 & 2606 \\
$\begin{array}{l}\text { Total number of personal } \\
\text { metadiscourse (raw frequency) }\end{array}$ & 211 & 62 \\
Normalized frequency (per 10000) & 23 & 8 \\
\hline
\end{tabular}

Commencement speech actually can be regarded as a kind of monologue, in which addressers pay much attention to the organization of the discourse to guide the audience toward the flow of discourse. Therefore, in both languages, metatext was used more frequently. In English commencement speeches, the three subtypes of reference to audience, speech act labels and discourse organization accounted for nearly the same percentage and they were the main discourse functions which metadiscourse served in English commencement speeches. In Chinese speeches, discourse organization was the most frequently used type of metadiscourse, which took up to nearly half of all those metadiscourse, and then the speech act labels and reference to the audience took up the rest of all metadiscourse. The subtype metalinguistic comments didn't occur in Chinese speeches.

\section{Metalinguistic Comments}

As shown in table 3, metalinguistic comments didn't occur in Chinese speeches, and this subtype accounted for smallest proportion in English speeches. This can be attributed to genre difference. The subtype repairing does not occur both in Chinese and English speeches, which is different from what Ädel (2010) and Mauranen (2012) discover about the use of repairing in their research. Repairing, as mentioned above, refers to self or other-initiated correctness of previous statement (Ädel, 2010). Ädel (2010) attributes the common presence of repairing to lack of time for planning and revision in real-time discourse. Although this is natural in speech, the absence of repairing in both English and Chinese speeches may due to the preparation of the addressers before delivery, the master of language for native speakers. What' more, university commencement speech is a kind of monologue which shows the presentation of addressers' views to the audience. Therefore, it's reasonable that repairing is absent in both sets of corpus. Similarly, the disappearing of managing terminology is also due to genre difference. The speeches selected in this study are delivered by famous people to university students, so the main aim is to help students develop excellent values and believes toward their future career and life. Therefore, these speeches are not concerning with some specialized terms which need to be defined.

In English commencement speeches, reformulating and clarifying are more often used than in Chinese. Since the speakers' identities are different, Chinese commence-

Table 2. Distribution analysis of metadiscourse subtypes

\begin{tabular}{|c|c|c|c|c|c|c|}
\hline \multirow[t]{2}{*}{ Metadiscourse subtypes } & \multicolumn{3}{|c|}{ English corpus } & \multicolumn{3}{|c|}{ Chinese corpus } \\
\hline & $\begin{array}{c}\text { Raw } \\
\text { no. }\end{array}$ & Percentage & $\begin{array}{c}\text { Normalized } \\
\text { frequency }\end{array}$ & $\begin{array}{c}\text { Raw } \\
\text { no. }\end{array}$ & Percentage & $\begin{array}{c}\text { Normalized } \\
\text { frequency }\end{array}$ \\
\hline \multicolumn{7}{|l|}{ Metatext } \\
\hline Metalinguistic comments & 26 & $12.3 \%$ & 2.8 & 0 & 0 & 0 \\
\hline Discourse organization & 58 & $27.5 \%$ & 6.3 & 28 & $45.2 \%$ & 3.7 \\
\hline Speech act labels & 63 & $29.9 \%$ & 6.9 & 20 & $32.2 \%$ & 2.5 \\
\hline \multicolumn{7}{|l|}{ Audience interaction } \\
\hline Reference to audience & 64 & $30.3 \%$ & 7.0 & 14 & $22.6 \%$ & 1.8 \\
\hline Total & 211 & $100 \%$ & 23 & 62 & $100 \%$ & 8 \\
\hline
\end{tabular}


ment speakers are presidents of university, while American university commencement speakers are famous people in various fields. The main content and the purposes of delivering the speeches are quite different. In China, the university presidents often provide their advices or expectations for graduates, then give some explanations. However, in English commencement speeches, the speakers with different careers and identities often share their personal stories or experiences with graduates and then put forward their suggestions and expectations. Chinese speaker don't need to reformulate something or clarify themselves. In English speeches, the function of clarifying which was used to spell out the addresser's intentions in order to avoid misinterpretation occurred most frequently. And then followed the function of reformulating. The rest discourse functions didn't occur in English speeches. The situation was different in Chinese corpus. Specially, all the discourse functions of this subtype didn't appear.

\section{Discourse Organization}

Table 4 displays the results of the distribution analysis of discourse organization functions. The category discourse organization is considered as a metatext metadiscourse that is primarily oriented toward the discourse dealing with topic and phorics management ( $\ddot{d} d e l, 2010)$. As can be seen, the distribution of different discourse functions in this subtype is very similar in English and Chinese speeches. Introducing topic, concluding topic and enumerating were both frequently used in two languages, which can be attributed to the organization of information before presentation. In English and Chinese speeches, introducing topic often occur at the beginning to catch audience attention and indicate what is going on in the following; enumerating shows the relation between a specific part with other parts of the spoken discourse, which can make the delivery more cohesive and coherent; concluding topic often occur at the end of a speech to make a summery. All these types show the clear organization of speeches and make the delivery more clearly presented to audience. On the contrary, the discourse functions delimiting topic, adding to topic, marking asides were absent in both speeches, which can be attributed to the well organization of information and the preparation of speech before delivery. What's more, since there were no handouts or slides for the audience when listening, endophoric marking didn't occur in both modes.

The major difference between two modes was the more frequent use of discourse organization function in Chinese speeches, which accounted for the largest proportion among four subtypes of metadiscourse. What's more, the subtype introducing topic is the most frequently used metadiscourse in Chinese commencement speeches. As can be seen in the following examples, in Chinese speeches, the structure of the commencement speeches is more fixed as advices plus

Table 3. Distribution analysis of metalinguistic comments

\begin{tabular}{lccccc}
\hline \multirow{2}{*}{ Metalinguistic comments } & \multicolumn{2}{c}{ English corpus } & & \multicolumn{2}{c}{ Chinese speeches } \\
\cline { 2 - 3 } \cline { 5 - 6 } & Raw no. & Percentage & & Raw no. & 0 \\
Repairing & 0 & 0 & $0.2 \%$ & 0 & 0 \\
Reformulating & 11 & 0 & 0 & 0 \\
Commenting on linguistic form/meaning & 0 & $7.1 \%$ & 0 & 0 & 0 \\
Clarifying & 15 & 0 & 0 & 0 \\
Managing terminology & 0 & $12.3 \%$ & & 0 \\
Total & 26 & & 0 & 0 \\
\hline
\end{tabular}

Table 4. Distribution analysis of discourse organization

\begin{tabular}{lcccc}
\hline Discourse organization & \multicolumn{2}{c}{ English speeches } & \multicolumn{2}{c}{ Chinese speeches } \\
\cline { 2 - 5 } & Raw no. & Percentage & Raw no. & $22.6 \%$ \\
\hline Introducing topic & 16 & $7.6 \%$ & 0 & 0 \\
Delimiting topic & 0 & 0 & 0 & 0 \\
Adding to topic & 0 & 0 & 6 & $9.7 \%$ \\
Concluding topic & 5 & $2.4 \%$ & 0 & 0 \\
Connecting topic & 15 & $7.1 \%$ & 0 & 0 \\
Marking asides & 0 & 0 & 5 & $8.1 \%$ \\
Enumerating & 14 & $6.6 \%$ & 0 & 0 \\
Endophoria marking & 0 & 0 & 1 & $1.6 \%$ \\
Previewing & 1 & $0.5 \%$ & 2 & $3.2 \%$ \\
Reviewing & 7 & $3.3 \%$ & 0 & 0 \\
Contextualizing & 0 & 0 & 28 & $45.2 \%$ \\
Total & 58 & $27.5 \%$ & & 0 \\
\hline
\end{tabular}


explanations, the addresser pays more attention to the flow of the whole speech. Thus, the discourse organization were most frequently used in Chinese speeches, which didn't mean discourse organization were not frequent in English speeches. Actually, the normalized frequency of discourse organization in English mode was higher than in Chinese.

(20) introducing topic: 说得真好！我为你们骄 傲, 你们成熟了, 但是我还是想多 说几句关于你们未来的叮咛。

introducing topic: good job! I'm so proud of you. You are mature, but I still want to say a few words about your future. (21) introducing topic: 默哀一分钟。默哀毕, 请坐下。请原谅我用如此伤感的这 段引言来开始我的讲话。

introducing topic: stand in silent tribute for one minute. End the silence, then sit down. Please forgive me for starting my speech with such a sad introduction.

(22) concluding topic: 做一个战士中的几句话 作为结束语, 与大家共勉。在这个 时代, 战士是最需要.

concluding topic: share with you a few words from $T o B e$ a Soldier as concluding remarks. In this age, what is most needed for soldiers...

(23) enumerating: 愧于这个伟大的时代? 在 这依依惜别的时刻，我想对同学们 提出三点希望：一、博学而笃...

enumerating: feel guilty of the great age? At this moment of parting, I'd like to put forward three expectations for my students: first, to be erudite and...

Another difference in this subcategory discourse organization between English and Chinese commencement speeches is the discourse function connecting topic. In English corpus, connecting topic accounted for the second largest proportion in this subcategory, while it didn't occur in Chinese corpus. The main cause for this phenomenon is that the focus of this study is personal metadiscourse. The metadiscursive expressions you know and you see frequently occurred in English discourse functioning as connecting topics. While in Chinese discourse, the equivalent metadiscourses "ni zhi dao" and "ni kan" didn't occur. Other expressions such as connectives which function as connecting topic in Chinese commencement speeches didn't contain personal pronouns, which made them excluded in Chinese personal metadiscourse.

\section{Speech Act Labels}

As for the speech act labels functions (see Table 5), arguing and exemplifying rarely occur in both speeches, which may be attributed to the limited material and too specific kind of speech act. What's more, the absence of arguing in both speeches is more likely to be genre-related, because arguing is more common in written mode where writers need to argue for or against a point that is crucial to their research, whereas speech generally presents or cites data and facts. The newly added subcategory saying was frequently used in both English and Chinese speeches. From example (24) to (27), it can be seen that speakers often use the words say or talk to remind readers of the main topic while bringing up some facts that are important to the argumentation.

(24) 同学们, 在今天的毕业典礼上, 我 要说, 你们今天收获的不仅仅是文 凭，更是自 信…

My dear students, at the graduation ceremony today, I have to say what you gain today is not just diploma, but also self-confidence...

(25) 在复旦学习的东西很多都是看似无 用的, 但我要说, 很可能复旦给你 们的这些貌 似无用的东西

In Fudan University, many things you've learned seem to be useless. But I have to say, it's likely that these seemingly useless things...

(26) gift than to see all of these folks graduate. I have to say, though, whenever I come to these

(27) all those geniuses who never get this chance? I'm talking about the young people from right here.

It is also noted that among the other speech act labeling subtype, English speeches employ more diverse speech acts such as call, say, suggest, mention, suppose, offer and so on. However, in Chinese speeches, these kinds of speech act labels were quite limited such as “回顾(look back)”, “回忆 (recall)”, “形容(describe)”.

\section{References to the Audience}

As for the second type of metadiscourse references to the audience (see Table 6), which focuses on audience interaction, managing comprehension, managing the audience discipline and imaging scenarios were less used in both languages. Commencement speech is more like a prepared presentation not dialogue between people and the content of the selected speeches are mainly related to values or believes in life not academic one, so the addresser seldom uses metadiscursive expressions to make sure the audience are with him. In terms of the discourse function managing the message which is typically used to emphasis the core message in what is being conveyed, or at least state what the addresser wishes the

Table 5. Distribution analysis of speech act labels

\begin{tabular}{|c|c|c|c|c|}
\hline \multirow[t]{2}{*}{ Speech act labels } & \multicolumn{2}{|c|}{ English speeches } & \multicolumn{2}{|c|}{ Chinese speeches } \\
\hline & Raw no & Percentage & Raw no & Percentage \\
\hline Arguing & 0 & 0 & 0 & 0 \\
\hline Exemplifying & 2 & $1 \%$ & 4 & $6.4 \%$ \\
\hline Saying & 30 & $14.2 \%$ & 11 & $17.7 \%$ \\
\hline Other speech act labelling & 31 & $14.7 \%$ & 5 & $8.1 \%$ \\
\hline Total & 63 & $29.9 \%$ & 20 & $32.2 \%$ \\
\hline
\end{tabular}


Table 6. Distribution analysis of references to the audience

\begin{tabular}{lccccc}
\hline References to the audience & \multicolumn{2}{c}{ English speeches } & & \multicolumn{2}{c}{ Chinese speeches } \\
\cline { 2 - 3 } \cline { 5 - 6 } & Raw no & percentage & & Raw.no & percentage \\
\hline Managing comprehension/channel & 3 & $1.4 \%$ & & 0 & 0 \\
Managing audience discipline & 0 & 0 & 0 & 0 \\
Anticipating the audience's response & 16 & $7.6 \%$ & & 2 & $3.2 \%$ \\
Managing the message & 13 & $6.1 \%$ & & 6 & $9.7 \%$ \\
Imagining scenarios & 1 & $0.5 \%$ & & 0 & 0 \\
Calling the audience attention to the following content & 31 & $14.7 \%$ & & 6 & $9.7 \%$ \\
Total & 64 & $30.3 \%$ & & 14 & $22.6 \%$ \\
\hline
\end{tabular}

audience to remember or experience based on the discourse (Ädel, 2010), both English and Chinese corpus employed such type of discourse function at the end of discourse to highlight the core message.

In both Chinese and English commencement speeches, the subtype calling the audience attention to the following content was frequently used. In example (28) (29), the expression "I tell you" is often used by addressers to call the audience attention and emphasize the following content.

(28) and I'm going to speak the truth of it! So I'm here today to tell you I have turned that netwo...

(29) 可能就业的情况与自己的期望值差 距比较大, 我要告诉大家的是不要 气馁, 要受得 住磨练

Maybe you are not satisfied with your current job, but what I want to tell you is not to be discouraged, but withstand the difficulty...

Due to the cultural difference that English is reader-oriented and Chinese is writer-oriented (Hinds, 1987), English addressers are more likely to interact with the audience, but Chinese addressers tend to speak indirectly and let the audience think by themselves. Therefore, reference to audience was more frequently used in English speeches than in Chinese speeches. In summary, English addressers use more personal metadiscourse in their speeches compared with that in Chinese, which may be attributed to the difference in language and culture.

\section{CONCLUSION}

In this study, a comparative analysis was conducted to examine the similarities and differences in the use of personal metadiscourse between Chinese and English commencement speeches. Also an attempt was made to explore the cultural, language and genre-based influences on the use of personal metadiscourse. Through data analysis, the results indicated some similarities and differences in two data sets. As for the similarities, both English and Chinese commencement speeches use metadiscourse as an effective resource to help the audience organize and interpret the ongoing text. And the addressers of both languages adopt more metatext metadiscourse than audience interaction, which reflects the monologic character of commencement speech. What's more, some discourse functions didn't occur in both modes such as repairing, commenting on linguistic form/meaning, delimiting topic, adding to topic, marking asides, endophoria marking and contextualizing due to genre difference.

With respect to the differences in two data sets, personal metadiscourse was more frequently performed in English speeches, especially the discourse function of references to the audience. These differences can be attributed to cultural and linguistic differences. English is reader-oriented and Chinese is writer-oriented (Hinds, 1987). English addressers are more likely to interact with the audience, but Chinese addressers tend to speak more indirectly and implicitly, which lead to the less use of personal metadiscursive expressions in Chinese speeches. In addition, Chinese is a parataxis language which means it needn't use linguistic forms to achieve coherence, and Chinese language is more loose in structure and has many no-subject sentences. On the contrary, English is a hypotaxis language which needs overt linguistic forms to connect phrases or sentences and to present logic meanings. Therefore, there were more metatext metadiscourse in English speeches than in Chinese speeches. As for Chinese commencement speeches, the structure is more fixed as advices or expectations plus relevant explanations, and the speaker are the president of the university, so the discourse organization metadiscourse such as introducing topic and concluding topic is more often used compared with other types of metadiscourse. Therefore, cultural, language and genre-based factors influence the use of personal metadiscourse in both English and Chinese commencement speeches. Specifically, genre features lead to some similarities in the use of English and Chinese personal metadiscourse, while cultural and linguistic factors lead to most differences in the two data sets.

This study has provided a descriptive and empirical study of persuasive function of metadiscourse in a single domain. Meanwhile, it also provides a way of studying Chinese metadiscourse based on corpus by employing Ädel's (2010) taxonomy of metadiscourse. Although many attempts have been made to provide reliable findings, more comprehensive studies examining larger bodies of data are needed. In order to develop a more comprehensive understanding of metadiscourse, it is desirable to investigate impersonal types of metadiscourse functions. This study can help public speakers build up knowledge about cross-cultural communication and adjust their persuasive strategies according to the expectation of the audience in English language cultural context. 


\section{REFERENCES}

Abdi, R. (2002). Interpersonal metadiscourse: an indicator of interaction and identity. Discourse Studies, 4(2), 139-145.

Ädel, A. (2006). Metadiscourse in L1 and L2 English. Amsterdam, Netherlands: John Benjamins Publishing.

Ädel, A. (2010). Just to give you kind of a map of where we are going: A taxonomy of metadiscourse in spoken and written academic english. Nordic Journal of English Studies, 9(2), 69-97.

Ädel, A. (2012). "What I want you to remember is...": Audience orientation in monologic academic discourse. English Text Construction, 5(1), 101-127.

Ädel, A., \& Mauranen, A. (2010). Metadiscourse: Diverse and divided perspectives. Nordic Journal of English Studies, 9(2), 1-11.

Amelia, M., Michela, C., \& Giuseppe, M. (2006). Rhetorical Argumentation in Italian Academic Discourse. Argumentation, 20(1), 101-124.

Beauvais, P. (1989). A speech act theory of metadiscourse. Written Communication, 6(1), 11-30.

$\mathrm{Bu}$, J. (2014). Towards a pragmatic analysis of metadiscourse in academic lectures: From relevance to adaptation. Discourse Studies An Interdisciplinary Journal for the Study of Text \& Talk, 16(4), 449-472.

Bunton, D. (1999). The use of higher level metatext in Ph.D theses. English for Specific Purposes, 18, 41-56.

Buttny, R., \& Hashim, A. (2015). Dialogue on "1 Malaysia": The uses of metadiscourse in ethnopolitical accounting. Discourse \& Society, 26(2), 76-78.

Cheng, X., \& Steffensen, M. S. (1996). Metadiscourse: A Technique for Improving Student Writing. Research in the Teaching of English, 30(2), 149-181.

Crismore, A. (1984). The rhetoric of textbooks: Metadiscourse. Journal of Curriculum Studies, 16(3), 279-296.

Crismore, A., Markkannen, R., \& Steffensen, M. (1993). Metadiscourse in persuasive writing: A study of texts written by american and finnish university students. Written Communication, 10(1), 39-71.

Dahl, T. (2004). Textual metadiscourse in research articles: a marker of national culture or of academic discipline? Journal of Pragmatics, 36(10), 1807-1825.

Gordon, C., \& Luke, M. (2016). Metadiscourse in group supervision: How school counselors-in-training construct their transitional professional identities. Discourse Studies, 18(1).

Guillem, S. M. (2009). Argumentation, metadiscourse and social cognition: Organizing knowledge in political communication. Discourse \& Society, 20(6), 727-746.

Hinds, J. (1987). Ch. 8, Reader versus writer responsibility: a new typology Writing across languages: analysis of L2 written text (pp. 141-152). Reading, Mass: Addison-Wesley.

Ho, V., \& Li, C. (2018). The use of metadiscourse and persuasion: An analysis of first year university students' timed argumentative essays. Journal of English for Academic Purposes, 33, 53-68.
House, J. (2009). Subjectivity in english as lingua franca discourse: The case of you know. Intercultural Pragmatics, 6(2), 171-193.

Hu, G., \& Cao, F. (2011). Hedging and boosting in abstracts of applied linguistics articles: A comparative study of English- and Chinese-medium journals. Journal of Pragmatics, 43(11), 2795-2809.

Hyland, K. (1998). Persuasion and context: The pragmatics of academic metadiscourse. Journal of Pragmatics, $30(4), 437-455$.

Hyland, K. (1999). Talking to Students: Metadiscourse in IntroductoryCoursebooks. English for Specific Purposes, $18(1), 3-26$.

Hyland, K. (2004). Disciplinary interactions: Metadiscourse in L2 postgraduate writing. Journal of Second Language Writing, 13(2), 133-151.

Hyland, K. (2017). Metadiscourse: What is it and where is it going? Journal of Pragmatics, 113, 16-29. doi:10.1016/j. pragma.2017.03.007

Intaraprawat, P., \& Steffensen, M., S. (1995). The use of metadiscourse in good and poor ESL essays. Journal of Second Language Writing, 4(3), 253-272.

Jiang, F., \& Hyland, K. (2017). Metadiscursive nouns: Interaction and cohesion in abstract moves. English for Specific Purposes, 46, 1-14.

Kelly, G. J., Cunningham, C. M., \& Ricketts, A. (2017). Engaging in identity work through engineering practices in elementary classrooms. Linguistics \& Education, 39, 48-59.

Kim, L. C., \& Lim, M. H. (2013). Metadiscourse in English and Chinese research article introductions. Discourse Studies, 15(2), 129-146.

Lee, J. J., \& Deakin, L. (2016). Interactions in L1 and L2 undergraduate student writing: Interactional metadiscourse in successful and less-successful argumentative essays. Journal of Second Language Writing, 33, 21-34.

Lee, J. J., \& Subtirelu, N. C. (2015). Metadiscourse in the classroom: A comparative analysis of EAP lessons and university lectures. English for Specific Purposes, 37(1), 52-62.

Li, C. (2009). A study of pragmatic functions of the discourse marker "you see". Foreign Language Education, 30(5).

Mai, H. (2016). An Intercultural Analysis of Meta-discourse Markers as Persuasive Power in Chinese and American Political Speeches. 4(6), 207-219.

Mauranen, A. (1993). Contrastive ESP rhetoric: Metatext in Finnish-English economics texts. English for Specific Purposes, 12(1), 3-22.

Mauranen, A. (2003). "But here's a flawed argument": Socialisation into and through Metadiscourse. Language \& Computers, 19-34.

Mauranen, A. (2010). Discourse Reflexivity -A Discourse Universal? The Case of ELF. Nordic Journal of English Studies, 9(2).

Mauranen, A. (2012). Exploring ELF: Academic English shaped by non-native speakers. Cambridge, UK: Cambridge University Press. 
Qiao, S. (2008). On the pragmatic function of discourse marker you know and it's chinese translation. Journal of Shangluo University, 22(3).

Ran, Y. (2002). On the pragmatic functions of the discourse marker "you know". Journal of Pla University of Foreign Languages, 25(4), 10-15.

Rintaniemi, H.-M. (2017). "Maybe we can just you know see how it's relevant": The use of you know as a discourse marker in academic elf interaction. (MA), University of Tampere.

Salas, M. D. (2015). Reflexive metadiscourse in research articles in Spanish: Variation across three disciplines (Linguistics, Economics and Medicine). Journal of Pragmatics, 77, 20-40.

Schiffrin, D. (1980). Meta-talk: Organizational and evaluative brackets in discourse. Sociological Inquiry, 50(3-4), 199-236.

Tang, K. S. (2017). Analyzing Teachers' Use of Metadiscourse: The Missing Element in Classroom Discourse Analysis. Science Education, 101(4), 548-583.

Thompson, S. E. (2003). Text-structuring metadiscourse, intonation and the signalling of organisation in academic lectures. Journal of English for Academic Purposes, 2(1), 5-20.

Valero-Garcés, C. (1996). Contrastive ESP rhetoric: Metatext in Spanish-English economics texts. English for Specific Purposes, 15(4), 279-294. doi: https://doi. org/10.1016/S0889-4906(96)00013-0

$\mathrm{Xu}, \mathrm{F}$. (2008). The relevance theory and the pragmatic function of the discourse marker you know. Journal of $\mathrm{Hu}$ zhou Teachers, 30(6), 66-70.

Yoon, H. J. (2017). Textual voice elements and voice strength in EFL argumentative writing. Assessing Writing, 32, 72-84.

Zare, J., \& Tavakoli, M. (2017). The use of personal metadiscourse over monologic and dialogic modes of academic speech. Discourse Processes, DOI: 10.1080/0163 853X.0162015.1116342.

Zhang, M. (2016). A multidimensional analysis of metadiscourse markers across written registers. Discourse Studies, 18(2), 204-222. doi:10.1177/1461445615623907

Zhang, M., Sun, W., Peng, H., Gan, Q., \& Yu, B. (2017). A multidimensional analysis of metadiscourse markers across spoken registers. Journal of Pragmatics, 117(2), 106-118. 